Religare, ISSN: 19826605, v.15, n.1, agosto de 2018, p.217-242

\title{
Nos limites do gospel: notas sobre música e religião evangélica
}

\section{Limits of gospel: notes on music and evangelical religion}

Emerson Giumbelli ${ }^{1}$

\section{Resumo}

Este trabalho busca discutir os limites que se estabelecem para a definição da música gospel no Brasil, tal como podem ser observados desde a cidade de Porto Alegre. A primeira parte dedica-se a uma igreja evangélica e o lugar da música em seus cultos. Percebe-se o estabelecimento de limites que, por sua vez, revelam a presença de inovações que podem ser associadas ao universo gospel. A segunda parte aborda uma banda de cristãos que integra o cast de uma gravadora secular. No caso desta banda, os limites se estabelecem para dificultar o seu trânsito para além de um circuito religioso, trânsito que está inscrito em sua proposta musical. O quadro mais geral em que se inserem as análises remete para as formas que assumem certas relações entre religião, música e cultura.

Palavras-chave: evangélicos, gospel, música religiosa, cultura

\begin{abstract}
This article aims to discuss the limits that are part of the definition of gospel music in Brazil based on research in the city of Porto Alegre. The first section is dedicated to an Evangelical church and and focuses on the place of music in its services. There are limits for the presence of music that, in turn, reveal the existence of innovations that can be associated to the gospel universe. The second section covers a Christian band that integrates the cast of a secular record label. In the case of this band, certain limits hinder their transit beyond a religious circuit, opposing the band's declared aims. The forms assumed by relations between religion, music and culture constitute the more general framework for the analyzes.
\end{abstract}

Keywords: Evangelicals, Gospel music, Devotional music, Culture

Dia 22 de outubro de 2017. Como parte da programação da Festa Nacional da Música, que se realizava naqueles dias em Porto Alegre, ocorria o Festival

\footnotetext{
${ }^{1}$ Professor Titular da Universidade Federal do Rio Grande do Sul, atuando no Departamento de Antropologia e no Programa de Pós-Graduação em Antropologia Social.
} 
Promessas. Com outras edições em outras capitais brasileiras, o Festival Promessas reúne em auditórios abertos artistas que são apresentados como "gospel" - ou seja, associados à música cristã. Por várias horas, 13 cantores/duplas/bandas se sucederam no palco ladeado por telões. Cada atração era apresentada pelo mesmo cantor, que é também responsável por um programa em uma rádio gospel da região metropolitana. $\mathrm{O}$ evento foi anunciado com várias semanas de antecedência em uma página virtual chamada "Agenda Gospel RS". O público foi estimado pelos organizadores em cerca de 50 mil pessoas; outros milhares puderam acompanhar os shows pela internet, na transmissão patrocinada pela principal rede de mídia brasileira. ${ }^{2}$ Certamente, a maioria desses espectadores pertence a alguma igreja evangélica, ajudando a alimentar as estatísticas que vinculam a esse universo religioso quase um terço da população do país. Outra parte dos espectadores representa o contingente que, mesmo sem ser evangélico, está potencialmente exposto - nos espaços públicos e nas mídias de massa - ao que uma autora caracteriza como a "explosão gospel" (CUNHA, 2007).

Este texto dedica-se a discutir alguns aspectos da realidade gospel - que é nacional e mesmo global - tal como pode ser abordada em Porto Alegre. De acordo com Olivia Bandeira (2017), na tese que elaborou sobre o tema, "a definição de música gospel e artista gospel não está nas músicas e nos agentes em si, mas no contexto de produção e consumo, que envolvem instâncias e agentes de legitimação como igrejas, gravadoras, mídia, artistas e consumidores" (p. 43). Assim, segundo a autora, o "mercado" é parte constitutiva daquele contexto de produção e consumo, de tal modo que hoje as igrejas evangélicas convivem com a possibilidade de carreiras artísticas entre seus membros e que tais artistas buscam colaboradores entre profissionais da indústria cultural. Em

\footnotetext{
2 Ver https://g1.globo.com/rs/rio-grande-do-sul/noticia/festival-promessas-reune-milhares-depessoas-no-anfiteatro-por-do-sol-em-porto-alegre.ghtml, acesso em 03/01/2018. Para a Agenda Gospel RS, ver https://www.facebook.com/agendagospelrs.
} 
contrapartida, gravadoras não religiosas passaram a desenvolver interesse em ter em seu cast artistas gospel. Se nos anos 1990 o gênero era dominado por empreendimentos vinculados ao universo religioso, depois disso temos a presença de empresas como Universal, Som Livre e Sony (PAULA, 2012). Entre os efeitos da consolidação do gospel no Brasil, estão a proliferação de muitos subgêneros musicais (rock, reggae, rap, etc) e o reforço da identidade genérica de “evangélicos" e de sua presença pública ([Autor]).

Reconhecer o papel do "mercado" na constituição do gospel não significa definir este a partir daquele, simplesmente. Essa é a crítica que Oosterbaan (2015) levanta ao trabalho de Cunha (2007), embora a contribuição deste para a compreensão do fenômeno seja inegável. O que está em questão não é a efetividade da relação com o mercado e sim a ausência de uma discussão atenta aos modos pelos quais essa relação ocorre. Críticas e conflitos nessa relação entre religião e mercado, sagrado e secular ocupam as páginas de Bandeira (2017), que mostra que em certos casos a conexão com a igreja ou a formação religiosa são considerados fundamentais para a legitimação de um artista como gospel e que, inversamente, gravadoras não evangélicas não desconsideram argumentos religiosos para justificar seu investimento no gospel. No contexto mexicano, Garma (2000) considera importante para a "música cristã" a conversão de artistas renomados que são reinseridos, a fim de serem autenticados, em um circuito autônomo de produção, distribuição e consumo de bens simbólicos. Oosterbaan (2015) aborda o caso do funk gospel no Rio de Janeiro, mostrando como são necessárias várias estratégias para desvincular a sonoridade das conotações e do estilo de vida - ambos demoníacos para muitos evangélicos - que lhe estão costumeiramente associados. Em suma, esses trabalhos sugerem que, tanto quanto a relação com o mercado, é constitutiva do gospel a operação que estabelece critérios de aceitação e legitimidade. Ou seja, quais são as diversas formas pelas quais, para evangélicos, se afirma o compromisso religioso por meio de produções culturais que circulam no "mundo secular"? 
Neste trabalho, busco discutir os limites que se estabelecem para a definição da música religiosa. Apresento a seguir os resultados de uma pesquisa que ocorreu no âmbito de um projeto mais amplo sobre as relações entre religião, cultura e espaço público. A pesquisa percorreu algumas igrejas evangélicas de Porto Alegre procurando compreender o impacto do gospel nas suas atividades. Uma dessas igrejas é abordada neste texto, não por ser mais representativa do que as demais, e sim por constituir uma situação em que - como em outras igrejas com resultados diferentes - se observa a tentativa de estabelecer limites que, por sua vez, revelam a presença de inovações que podem ser associadas ao universo gospel. A parte restante do texto dedica-se a analisar o material mais volumoso da pesquisa, referente a uma banda de que ouvi falar na igreja de que trata a primeira parte e que voltei a encontrar no festival descrito no início. No caso desta banda, os limites se estabelecem para dificultar o seu trânsito para além de um circuito religioso, trânsito que está inscrito em sua proposta musical. Abordando suas formas de apresentação - em pronunciamentos, em performances e composições artísticas - empreendo uma caracterização dessa proposta e de seus dilemas. Pretendo com a discussão dessas duas situações contribuir para a problematização dos modos pelos quais o gospel se constitui no Brasil.

\section{O gospel em uma igreja}

A Igreja Batista Mont Serrat (IBMS) deve seu nome ao bairro em que inicialmente se localizava em Porto Alegre. Atualmente ela ocupa um edifício no qual funcionavam os escritórios de uma entidade filantrópica ligada a uma empresa de aviação. No mesmo prédio estão abrigados o templo da IBMS e a sede de uma escola de aviação. Na internet não se encontram muitas informações sobre a história ou a estrutura dessa igreja. As observações mostram que é frequentada por pessoas de classe média e classe média alta. Contando com cerca de 1300 membros, é uma igreja com pretensões missionárias voltadas para o 
exterior. Ela é vinculada à Convenção Batista Brasileira, uma organização que congrega igrejas não pentecostais. Embora a IBMS não se caracterize como pentecostal, seu culto traz marcas de avivamento e de influências carismáticas. Um ponto que demonstra isso é exatamente a forma da e com que a música é incorporada a suas atividades. Além de estar presente em todas elas - mas, como veremos, não da mesma maneira -, a música é a expressão mais clara da penetração do gospel nessa igreja. Isso não significa que não haja uma preocupação com essa penetração, na tentativa de estabelecer limites e critérios para ela.

O salão é espaçoso, organizado por fileiras de cadeiras de plástico largas e confortáveis. O despojamento protestante impera, confirmado pela presença isolada, próxima ao púlpito, de uma cruz de madeira encostada a uma parede. Mas a descrição seria incompleta se buscasse apenas por elementos claramente religiosos. Pode-se notar que o fundo do salão, para onde se dirigem as atenções dos fiéis, é preenchido por instrumentos musicais e por três telões. Amplificadores sonoros, mesas de som e projetores ocupam seus lugares. Tratase, portanto, de um ambiente fortemente mediatizado, no sentido de que as atividades que ali se realizam envolvem uma parafernália que lhes confere sua forma específica. Os smartphones dos fieis por meio dos quais consultam passagens bíblicas ou postam imagens nas redes sociais são também parte dessa mediatização. Os telões servem para a projeção de textos em que as pregações se apoiam. Servem ainda para a projeção das letras das músicas que são executadas no salão, algumas das quais poderão ser encontradas nos encartes de CDs vendidos na livraria que existe dentro do prédio. Essa livraria oferece livros de vários gêneros, camisetas com dizeres bíblicos, acessórios de uso pessoal que incluem o logotipo da IBMS - em suma, um conjunto de artigos que inclui a igreja no circuito de distribuição do gospel, inclusive suas músicas.

Para entendermos as características dos cultos que ocorrem na IBMS, é útil nos remetermos às observações de Sant'ana (2017), que por sua vez se beneficiam das amplas análises de Cunha (2007). Sant'ana refere-se a determinadas igrejas 
evangélicas nas quais "o culto adquiriu definitivamente uma forma musical". Isso significa que "as curas, as glossolalias e outras manifestações do Espírito Santo acompanham a música que organiza o clímax do culto, os momentos de oração e toda a experiência dos fiéis" (p. 64). Nessa descrição, portanto, a música insere-se em todas as etapas da atividade religiosa. Isso corresponde à exacerbação conferida ao que é designado nas igrejas evangélicas como "louvor". A palavra costuma ser utilizada para se referir ao momento do culto em que a música ganha protagonismo. Tradicionalmente, as canções são escolhidas entre "hinários" que compilam composições de várias épocas, algumas tão antigas quanto a Reforma. Mas nos cultos descritos por Sant'ana o repertório incorpora canções recentes e mesmo composições originadas na própria igreja. Como nota Garma (2000), o "louvor" deixa de ser apenas uma etapa do culto e se torna qualificativo de um gênero musical que em sua difusão extrapola as paredes do templo. Deparamo-nos assim com o estilo "louvor e adoração", que segundo Bandeira (2017) detém a hegemonia no universo da música gospel.

Na IBMS, os cultos dominicais que foram observados nos meses finais de 2017 cumprem uma sequência que revela a distinção entre três momentos básicos: oração, louvor e pregação. Nessa organização, a música fica restrita ao segundo dos momentos, sob a responsabilidade de uma banda (guitarra-baixobateria-teclado) acompanhada de um coro de vocalistas. Nesse sentido, a IBMS busca manter a forma tradicional que caracteriza os cultos evangélicos. Essa reiteração é reforçada por um contraponto que serve ao mesmo tempo para resguardar o culto dominical e para acomodar inovações que são abrigadas em outras atividades. Isso ocorre na "Festa de Levi", a qual tem lugar nos sábados e é voltada aos jovens que frequentam a IBMS. As observações mostram que há duas diferenças básicas entre a atividade dos sábados e a dos domingos. Primeiro, não há a etapa da oração e a pregação é feita por um pastor dedicado ao público, podendo ser complementada pela mesma pessoa que fica responsável pelas canções entoadas pela banda. Portanto, a música adquire uma centralidade maior. Segundo, há uma diferença no "estilo de música", como explica o pastor 
responsável pelo ministério de louvor na IBMS: "no domingo é um estilo mais voltado para um grupo misto, tem crianças, jovens, adultos e velhos. No sábado, é um público mais jovem, então tem mais rock'n'roll, tem reggae, tem uns estilos mais a ver com esse público".

As distinções entre a "festa" e o "culto" precisam, no entanto, ser relativizadas. O propósito de tal relativização é apontar que as inovações não estão confinadas à atividade dirigida aos jovens, mas penetram aquele que é o principal evento da IBMS. Voltemos então ao culto de domingo. Durante o momento de louvor, os movimentos dos fiéis, quando acompanham as músicas cantando as letras e agitando os corpos, não se diferenciam nitidamente do que se observa no sábado. Trata-se de uma coreografia que busca retratar o equilíbrio almejado entre contenção e avivamento, entre religiosidade e secularidade. Em oposição, como vimos, à festa de sábado, que é aberta ao rock e ao reggae, a música apresentada no domingo é chamada de "congregacional". Ocorre que as características dessa música "congregacional" revelam inovações significativas. Os cultos dominicais não utilizam os hinários protestantes tradicionais. Preferese, como esclarece o pastor já citado, "músicas que são fáceis de serem cantadas como igreja, todo mundo junto". A observação do repertório mostra que ele é composto por canções que correspondem ao mainstream do gênero "louvor e adoração", que não exclui elementos do rock e do reggae, por exemplo, e ao mesmo tempo permitem a inserção de pregações. Às vezes, a banda da IBMS dá lugar para convidados. O culto do dia $1^{\underline{0}}$. de novembro contou com a presença do "Diante do Trono", que com seu pop-rock é uma das principais referências da música gospel no Brasil.

Na Festa de Levi, também há espaços para convidados. No dia 20 de dezembro de 2014, o espaço do templo da IBMS foi dedicado à apresentação de uma banda chamada Tanlan. Cerca de 500 pessoas estiveram no show, que prosseguiu mesmo com a queda da energia elétrica. Parte do público era composto por adultos de meia idade, frequentadores dos eventos da IBMS ou acompanhantes dos demais. Estes eram mais novos, ligados ao grupo de jovens 
da igreja, entre os quais muitos cantavam juntos com a banda as suas canções. Tratava-se da celebração natalina da IBMS, o que não impediu a cobrança pelo ingresso, que custava o valor aproximado de cinco latas de refrigerantes compradas em um supermercado mais a entrega de um quilo de alimento não perecível. O evento foi divulgado na Agenda Gospel RS e até mesmo em uma rádio evangélica de Porto Alegre. Os mesmos canais propagandearam o show que a Diante do Trono realizou na capital gaúcha em agosto de 2013. O local foi uma casa de espetáculos que costuma receber bandas sem marcas religiosas. Como já descrevi em outro texto (referência suprimida), o que assisti foi um misto de show e culto, algo que é bastante revelador sobre as características do universo gospel. Apesar da Tanlan participar desse universo, como demonstra sua presença na IBMS, e de ela almejar estar na mesma casa de espetáculos em que se apresentou a Diante do Trono, seus integrantes certamente detestariam aproximações com a banda que representa o mainstream do gospel brasileiro. A Tanlan quer ser alternativa. É hora de vermos como elabora e realiza sua proposta.

\section{A música cristã para além do gospel}

\subsection{Banda de bar}

Tanlan é uma banda de rock radicada em Porto Alegre formada por quatro rapazes. Teve início por volta de 2003 e no final de 2016 lançou seu terceiro CD. Os CDs anteriores vieram a público em 2012 e 2008 - o mais antigo incluindo músicas já divulgadas em 2005. O rótulo que acompanha a banda é "rock/pop/indie/alternativo". Às vezes eles se identificam simplesmente como uma banda de "rock moderno". Uma das casas de show em que se apresentaram, conhecida na cidade como parte do circuito "alternativo", descreveu assim a banda: “a Tanlan se destaca pelas letras reflexivas e o som redondo, com melodias de sair cantando na primeira ouvida, mas sem serem descartáveis e 
pobres". ${ }^{3}$ No show, que eu assisti, a banda tocou uma música dos Foo Fighters, que o mesmo texto cita como uma das suas influências musicais. O primeiro CD foi saudado pela revista Noize como um indie apropriado para "adentrar o mainstream": "os refrães são grudentos como o pop rock tem que ser; e a produção é caprichada e minuciosa". ${ }^{4}$ Cumprindo a profecia, em 2012 a banda passou a integrar o cast de artistas da Sony, umas das maiores gravadoras em atuação no Brasil.

A descrição acima corresponde ao modo como a Tanlan foi idealizada: "uma banda formada de cristãos, mas que não toca música gospel". A afirmação é do vocalista Fábio Sampaio, em uma das duas entrevistas que concedeu à pesquisa. ${ }^{5}$ Essa recusa do "gospel" passa por dois pontos. De acordo com Fábio, o que se consagrou como gospel no Brasil é uma música que segue sendo "funcional", ou seja, ela está a serviço da atividade de culto e constitui uma parte deste. Assim, a adoção de ritmos contemporâneos não significou uma mudança de concepção musical; na verdade, teria resultado em um empobrecimento artístico. O segundo ponto é que tal concepção estava adequada a um circuito de apresentações limitado, que Fábio chama de "convencional": além dos próprios templos, eventos organizados pelas igrejas, inclusive em praça pública. Ouçamos o cantor: "Como se criou essa visão de que tudo o que um crente faz tem que ser gospel, a gente quis romper com isso. Então nós dissemos 'não, o que eu faço é música'. Quem vai ouvir vai se relacionar com ela como música. Então eu vou tocar onde eu puder tocar". A ideia serve inclusive para justificar a escolha da Sony como empresa de distribuição da banda, em detrimento de outra gravadora que trabalha especificamente com música gospel. A mesma ideia impõe limites às performances, como Fábio esclareceu em sua segunda entrevista para a pesquisa: não entrar com uma bíblia no palco e nem pregar no meio do show. ${ }^{6}$

\footnotetext{
${ }^{3}$ http://barocidente.com.br/festa/see/quartas-do-ocidente/549, acesso em 13/12/2017.

${ }^{4}$ Noize n. 15 nov 2008.

${ }^{5}$ Quando não estiverem referidas a outras fontes, os posicionamentos creditados a Fábio Sampaio foram registrados nessas entrevistas, realizadas em 26/02/2015 e 07/11/2017.

- Com esse ideário, a Tantan reivindica fazer paž de um "novo movimento", junto com outros artistas no Brasil. Ver os trabalhos de Muller (2014) e Oliveira (2013) para a caracterização dessa
} 
Fábio resume a proposta da Tanlan na imagem de uma banda de bar. A apresentação no Ocidente, descrita acima, corresponde a essa imagem. Ao longo de sua trajetória, a banda coleciona registros semelhantes, sobretudo no período inicial. O primeiro $\mathrm{CD}$ foi lançado em um show em outra casa do circuito "alternativo" de Porto Alegre; a banda participou do evento ocorrido em uma estação de trem promovido por uma rádio não religiosa; a Tanlan se apresentou duas vezes em um programa da TVE local. No segundo deles, de 2015, a conversa com o apresentador passou primeiro por temas que integram a pauta de qualquer banda. Tratou-se, por exemplo, dos profissionais envolvidos na produção do segundo CD. Apenas no último bloco aparece menção à religião dos membros. "Viemos de um meio cristão", reconhece Fábio, que complementa: "mas produzimos arte sem rótulo, para todos os públicos". ${ }^{7}$ Se notássemos as roupas que os quatro rapazes usavam nessa ocasião, nada permitiria identificá-los como cristãos. Isso se repetiria em 2014 no show que a banda fez em um evento promovido pelo principal jornal do Rio Grande do Sul em um parque de Porto Alegre. Como pude observar, referências cristãs apareciam não no visual da banda, mas nas camisetas de alguns dos jovens que cantavam as músicas no público.

A opção por uma estética que recusa identificação com referências religiosas é reafirmada nas capas dos álbuns e nos videoclips da banda. Uma paisagem desenhada, a foto de um grande corredor, a imagem de uma pessoa sentada sob um céu de tempestade ilustram, respectivamente, os CDs, cujos nomes são: Tudo o que eu Queria, Um Dia a Mais, Acalmanocaos. Sobre os videoclips, três estão destacados na webpage da Tanlan. Em um deles, o mais antigo, os quatro integrantes são filmados em uma performance de estúdio. Em outro, novamente aparecem tocando seus instrumentos, dessa vez em um prédio de arquitetura modernista, em imagens que alternam ambientes degradados com 
partes reformadas. O mais recente dos videoclips é uma composição que mistura a técnica de stop motion (pela qual as imagens dos rapazes formam quase uma animação) com uma espécie de storyboard que permite visualizar a letra da canção. Um dos comentários junto ao segundo vídeo faria a banda pensar que há pessoas entendendo sua proposta: "Vocês sabem fazer música boa com letras positivas sem soar algo religioso".${ }^{8}$ Mas se notarmos que ele vem acompanhada da hashtag "GodBless", ele nos introduz em uma dimensão que é fundamental para se entender o que a Tanlan faz quando faz música.

\subsection{Poética teológica}

Para isso, nada mais adequado do que uma análise das letras. Em pesquisas sobre o gospel, esse é um aspecto sempre presente. Parece ser uma regra que a contrapartida para a assimilação de diversos gêneros musicais pelos evangélicos é a ênfase nas letras, cujo conteúdo deve deixar explícito a identidade religiosa dos compositores e dos artistas. Nas palavras de Jungblut: "esses jovens evangélicos precisam demonstrar que, apesar de serem crentes, podem incorporar e manipular o repertório simbólico característico desse universo [o underground] com a mesma desenvoltura e naturalidade de seus pares nãoevangélicos sem, contudo, deixar de afirmar explicitamente sua confissão religiosa" (2007, p. 157). O foco mais específico de Jungblut é o do white metal, no qual limitar-se nas letras a citar "Senhor" em vez de "Jesus" é um fator de desconfiança acerca da autenticidade religiosa das bandas. Algo semelhante ocorre em outros gêneros que integram o gospel, como mostram os trabalhos de Oosterbaan (2015) sobre o funk e de Guerreiro (2016) sobre "os corinhos de fogo" que se apresentam em ritmo de forró, pagode e axé. Em ambos os casos, são comuns nas letras temas que caracterizam a teologia da batalha espiritual, com referências religiosas explícitas.

${ }^{8}$ https://www.youtube.com/watch?v=DrJ8Mm-JvhA, acesso em 13/12/2017. 
Já as letras da Tanlan não mencionam Deus ou Jesus. Antes de vermos melhor o quê e como mencionam, é útil observar que o gênero em que atuam - o rock - é menos marginal no universo gospel do que o metal, o funk ou o forró. É possível afirmar que o rock como sonoridade já foi incorporado a algumas das vertentes sonoramente dominantes no gospel. ${ }^{9}$ Carvalho (2017), que comenta essas hierarquias estéticas, dedica-se ao caso de um artista gospel que coloca em cena outro gênero musical. Trata-se do rap, em torno do qual, ao menos no Brasil, se desenvolveram aproximações sui generis com referências religiosas, como demonstrou Novaes (1999). Artistas não religiosos incorporam imagens e citações bíblicas a suas letras, as quais muitas vezes se assemelham a pregações seculares. O rapper evangélico abordado por Carvalho (2017) é um exemplo de artista amplamente reconhecido no mundo hip hop em geral - não apenas no gospel. Seu trabalho conjuga reflexões e incursões por temas que cobrem não apenas a religião, mas também política e raça. O universo em que se desloca uma banda como a Tanlan é diferente. Sobre ele não pesam desconfianças tão fortes quanto aquelas que vindas do gospel se dirigem ao funk ou ao forró, mas ele também não compartilha da proximidade desenvolvida entre a religião e a não religião no rap. Permanece a questão: como ser religioso fazendo rock?

No caso da Tanlan, a análise das letras foi realizada com o conhecimento prévio de que se tratava de uma banda formada por cristãos e que não deixa de ser identificada como "gospel". Para quem busca informações sobre a banda, essa identificação é facilmente encontrada. Em primeiro lugar, a Tanlan está elencada entre os artistas gospel da Sony, que a inseriu em coletâneas gospel e a indicou para uma premiação de música gospel. Na versão atual (novembro 2017), há poucos dados no website da banda. Mas o verbete da Wikipedia traz um relato histórico que já esteve disponível no website e que aponta a seguinte questão como motivação central do grupo: "Por que o cristianismo e a música cristã parecem tão desconexos do mundo em que vivemos? Será que o cristianismo

\footnotetext{
${ }^{9}$ Isso varia de acordo com quadros nacionais. Para o México, ver Garma (2000). Para a Argentina, ver Mosqueira (2016). Para os Estados Unidos, ver Chamg e Lim (2009).
} 
poderia não ter nada a dizer para o 'mundo real'? Será que a música cristã precisava ficar restrita a um gueto?". ${ }^{10}$ Fica claro para quem lê o verbete que se trata de uma proposta de inspiração religiosa. Quando Fábio Sampaio foi entrevistado pela primeira vez para a pesquisa, ele disse que as músicas da Tanlan se propõem como anti-jingles: elas não pressupõem um aval prévio, nem oferecem uma receita de como devem ser entendidas. É importante que elas permitam uma fruição estética, tanto na sonoridade quanto nas letras. Se a pessoa, completa Fábio, "quiser saber do que eu tô falando, e quiser estudar a minha vida, ela vai descobrir do que eu tô falando".

Na verdade, essa resposta de Fábio reagiu a uma observação que surgira da primeira incursão às letras de músicas da Tanlan. Há várias músicas - há pelo menos quatro no primeiro CD e outras quatro no segundo - nas quais a letra se dirige a um "tu" ou "você" que pode ser ocupado pela pessoa amada. "Sobre o amor", do segundo CD, é um exemplo, com o seu refrão assim: "Vem me ensinar sobre o amor / Vem completar quem eu sou / Me transformar e preencher / Tudo o que foi e o que vai ser". "Vim Dizer", do primeiro CD, enquadra-se no mesmo formato, como podemos ver nessa estrofe - “Vim pedir o teu perdão / Teu amor em minha vida / Sem palavras pra dizer / Vou viver pra te amar" - e na seguinte - “Ter em meus olhos as marcas da dor / Por ter ferido teus sonhos pra mim / Posso em teus braços sentir o calor / Traz aos meus lábios teu toque de amor". Quando perguntei a Fábio quem seria o destinatário de letras como essas, ele disse: “o que eu faço é arte, eu não quero limitar a interpretação, se o cara acha que aquilo é para a mulher dele, pode cantar pra mulher dele. Se ele quiser saber do que eu tô falando..."

Em certo sentido, portanto, as letras da Tanlan não destoam do estilo "louvor e adoração" que predomina no gospel. O próprio nome confirma isso: em uma língua chinesa, "tan lan” designa o inseto que chamamos de louva-adeus. De todo modo, é certo que há toda uma teologia implícita nesse conjunto

\footnotetext{
${ }^{10}$ https://pt.wikipedia.org/wiki/Tanlan, acesso em 13/12/2017.
} 
de textos, ainda que nomes divinos não sejam enunciados. Além do louvor, outro tema que atravessa as letras caracteriza o ser humano como alguém que busca e que reconhece suas imperfeições. "Vaidade", que encerra o segundo CD e foi composta segundo Fábio tendo o livro bíblico de Eclesiastes como inspiração, termina assim: "A vaidade das vaidades, um vazio sem fim / A busca da realidade é o que me trouxe aqui". "Eu me perco em meu deserto", canta Fábio em "Do Início ao Fim", do último CD, até chegar ao refrão: “De você / Vida que transcende o que se vê / Todo amor que eu já pensei viver / Do início ao fim / Me salvando de mim". Esse refrão, aliás, ratifica a possibilidade da dupla leitura sobre o destinatário dessa mensagem.

O destinatário, no entanto, nem sempre é a pessoa amada ou um ente divino. Há letras que se endereçam claramente a uma outra pessoa e não mobilizam vocabulários românticos. Essa modalidade apresenta duas variantes. Na primeira, a música busca fazer alguém despertar, sair da situação negativa em que é descrito. "Fingir", do segundo CD, é um exemplo: “Não, não vale a pena se esconder / Cruzar os braços, fingir não ver / Que a vida é mais que viver agora / E tem bem mais pra te oferecer." Na segunda modalidade, esse alguém a quem a música se dirige é tratado com empatia. "Bem Vindo", do primeiro CD, ilustra isso: "Bem vindo ao mundo eu espero que você se sinta bem aqui / Bem vindo à vida real / Agora todo mundo quer saber o que você irá fazer". Outro exemplo, do segundo CD, é “De onde vem", na qual fica mais clara como "eu" e "você" compartilham da mesma situação: "Eu sei que um dia eu vou / Viver num lugar melhor pra mim / Quem sabe você também / Um dia descubra como ir / Pra um lugar onde o amor é mais / Do que tudo o que você já provou / Um lugar onde não há mais dor." Ambas as modalidades são comuns em letras de poprock, mas no caso da Tanlan elas se articulam aos demais temas que constituem o que chamei aqui de teologia.

Para a banda, essa teologia não é simplesmente acoplada à vida em forma de música; ao contrário, à música cabe expressar uma atitude total. Fábio nos explica, defendendo a prescindibilidade da menção a Deus nas letras: "se eu 
acredito realmente no que eu acredito, aquilo que eu vivo vai transbordar na minha composição". Após o show já mencionado em um parque de Porto Alegre, a banda concedeu entrevista aos promotores do evento. Nela surgiu o tema da religião, e os integrantes usaram a seguinte expressão para definir o que fazem: "Não ficamos falando de Jesus, mas deixamos que as pessoas vejam Jesus na gente" ${ }^{11}$ Isso se refletiria em certos aspectos das apresentações, como no respeito aos horários acordados e à equipe de apoio, na relação com o público, em não usar o palco para atrair mulheres ou para vociferar palavrões... Fábio gosta de citar o caso de um bar no Maranhão, que contratou a banda sem saber de sua conexão com a religião; após o contratante ter ficado bem impressionado com a performance e com o comportamento dos músicos, renovou o convite sabendo que se tratava de rapazes cristãos.

Se alguém tivesse que escolher um tema que descreva a teologia expressa nas letras da Tanlan, ele seria provavelmente o amor. Esse é o ponto central de várias músicas, como "É mais", "Louco Amor" e "Me conjugou”, escolhidas de cada um dos três álbuns. No último álbum, apenas em uma das letras a palavra não aparece. "Me conjugou” pode ilustrar a ideia - central na teologia da banda - de que toda relação com Deus é uma relação com outra pessoa: "Pra viver o novo com você / Aprendendo a respirar / Ouvir pra depois falar / Conhecendo mais quem é você, essa relação é parte do projeto de / Espalhar a paz que eu encontrei / No dia que o verbo amar me conjugou". “O que vai ficar", também do último álbum, é uma espécie de síntese daquela ideia: a relação com outrem “E o que mais importa / No caminho percorrido / É marcar a vida de / Quem vai ficar" - apontando para algo transcendente - "Quanto tempo gasto em tantas coisas pra ninguém / E o que importa agora é o que me leva mais além". Afinal, "o amor, amor, amor / é o que vai ficar". Mas há quem não se satisfaça com isso, como revela o único comentário negativo que acompanha o clip dessa música:

\footnotetext{
${ }^{11}$ https://www.youtube.com/watch?v=s8t8FycbDww, acesso em 13/12/2017.
} 
“Qual amor? O pessoal pra não se mostrar associado a ideias cristãs, gritam pelo amor." 12

\subsection{Banda de crente}

Na verdade, o álbum que inclui essa faixa foi apresentado pela banda como mais "confessional" que os anteriores. Assim escreve o release que acompanha o lançamento de Acalmanocaos: "Resultado de um processo longo, que envolveu questionamentos e conflitos internos, o disco pela primeira vez evoca temas espirituais com mais profundidade e de forma não tão sutil, como em 'Epifania', que fala sobre a graça de modo confessional."13 A faixa mencionada tem um andamento mais lento do que a maior parte das músicas da banda - seria então uma confirmação do que o mesmo texto aponta, a sonoridade "mais pop" do terceiro álbum - e sua letra confessa as imperfeições de quem a canta, chegando no refrão: “Mas tua graça é mais / Teu amor é o que me traz / pra mais perto de tua paz / Sem me esquecer jamais." Na entrevista, realizada no período das comemorações do quinto centenário da Reforma, Fábio Sampaio não deixou de lembrar que a graça é um dos pilares do protestantismo. A música também ganhou um videoclip e um dos comentários parece responder perfeitamente às intenções da banda: "que canção linda, que mensagem do evangelho, bem diferente da música gospel (rasa e sem profundidade)" ${ }^{14}$

O enunciado de uma "mensagem do evangelho" mais explícita sem abdicar da recusa ao gospel pode ser encontrado em outras músicas da trajetória da Tanlan. Outra faixa do terceiro álbum onde isso ocorre é "17", que se refere ao "autor de todo amor" de uma maneira menos ambígua que as letras que aceitam uma interpretação romântica. No primeiro álbum encontramos "Simplesmente", da qual se pode dizer o mesmo que se aplica a "17", pois se trata de "entregar

\footnotetext{
${ }^{12}$ https://www.youtube.com/watch? v=jWfiNNvltRg, acesso em 13/12/2017.

${ }^{13} \mathrm{http}: / /$ www.tanlan.com.br/single-post/2016/12/26/TANLAN-LAN\%C3\%87AACALMANOCAOS-TERCEIRO-E-MAIS-POP-DISCO-DA-CARREIRA, acesso em 13/12/2017. 14 https://www.youtube.com/watch? $v=1 Q$ C (P2D232ak, acesso em 13/12/2017.
} 
minha vida" e de "entender a razão de se viver". Mais explícita mesmo é a faixa que abre o álbum, "Aonde Vou", que ao expor as reflexões sobre o além vida trata também da origem do mundo: “Toda a beleza da criação / Tudo é reflexo de tuas mãos / Uma vontade e houve a luz / Um sentimento e trouxe a cruz /Para que todos saibam dizer". E talvez nada diga melhor quando a ideia é ser explícito do que uma música do segundo CD, “Meu nome meu sangue”. Em contraste com a sonoridade de "Epifania", essa faixa traz a Tanlan com batidas não lineares e guitarras distorcidas, marca de várias de suas músicas. Ainda que a estrofe inicial possa sugerir que se trata de uma pessoa se dirigindo a outra, o desenrolar da letra não deixa dúvidas de que o eu lírico é, na visão cristã, aquele que morreu na cruz para salvar cada um de nós: “Cada prego que perfura a minha mão / É uma gota do meu sangue que vai te trazer / Mais perto do meu coração / Perto do que eu mais sonhei pra você."

Quando alguém procura pela Tanlan na plataforma Deezer, depara-se com um álbum chamado "Mensagens Devocionais". O álbum, que só existe nesse formato digital e foi disponibilizado em abril de 2017, é composto de pequenas histórias contadas pelos integrantes da banda com um fundo musical. Bem antes disso, em dezembro de 2013, a banda havia disponibilizado uma faixa com o título "É Natal". Ela é acompanhada de um videoclipe em estilo "making of" que mostra a participação de crianças juntamente com o que podem ser familiares da banda. A sonoridade não destoa de outras canções mais pops da Tanlan e a letra não menciona Jesus (mas "anjos" sim). De todo modo, não é comum que bandas de "rock/pop/indie/alternativo" façam "músicas de natal". Quando busquei por músicas da Tanlan na plataforma Soundcloud, notei que havia uma faixa que destoava da rotulação predominante. Nesse caso, o rótulo era "worship pop rock". Questionado sobre isso, Fábio contou que houve um pedido da produtora (que, aliás, é dedicada ao circuito gospel) de shows da banda para que gravassem alguma música "de crente". "Nós compomos músicas congregacionais, mas não é nosso interesse divulgar". Contudo, diante do pedido da produtora, gravaram três faixas, incluindo "um hino antigo com roupagem nova". 
Esse pedido teria ocorrido por volta de 2009, ou seja, pouco tempo depois do lançamento do primeiro álbum. A justificativa, segundo Fábio, era que havia dificuldade de agendar shows no circuito evangélico. Ou seja, a proposta de ser uma banda de bar estabeleceu certa tensão com o universo religioso a que se filia a Tanlan. A julgar pela agenda de apresentações, essa tensão foi respondida com um movimento em direção ao circuito evangélico. Na primeira entrevista, realizada no começo de 2015, Fábio reconheceu que "nos últimos três anos, a banda estava se apresentando mais no ambiente evangélico". Na segunda entrevista, ocorrida no final de 2017, Fábio afirmou que, nesse ano, na sua memória não havia registro de apresentações fora daquele "ambiente". Consequentemente, a ideia de ser uma "banda de bar" foi reformulada: "Hoje somos uma ponte que tende pro lado do gospel". É aí, admite Fábio, que a banda encontra um público maior e mais receptivo. $\mathrm{O}$ circuito ou ambiente evangélico inclui tanto eventos gospel ou religiosos quanto apresentações em igrejas.

O reconhecimento de ter se tornado uma "ponte" tem implicações para a forma pela qual a banda pretende cumprir uma regra de separação: "somos artistas, não ministros". A Tanlan defende que haja clareza na distinção entre palco e púlpito. Isso é outra fonte das críticas ao "gospel". A proliferação e circulação de "ministérios de louvor" criou, segundo Fábio, uma situação mal resolvida, pois esses ministérios definem seu trabalho como algo evangelístico ou missionário e ao mesmo tempo querem ser tratados como artistas com direito a "camarim e cachê". A Tanlan se identifica como uma banda que faz shows. Almeja frequentar o circuito que os evangélicos chamam de "secular" e não aceita se apresentar em cultos. No entanto, essas disjunções são relativizadas na prática. Antes de mostrar como isso ocorre, é importante registrar que os rapazes da Tanlan participam das atividades musicais nos cultos da igreja a que se filiam. Trata-se de uma igreja batista em Porto Alegre que Fábio define como "tradicional com um pé no avivado". Segundo ele, mais tradicional que a IBMS, que seria "quase pentecostal". Isso significa que, nos cultos da igreja batista a que pertencem, os membros da Tanlan tendem a desempenhar um papel de músicos 
congregacionais. ${ }^{15}$ É significativo que a banda tenha feito apenas um show nessa igreja. Mas em outros espaços eles podem ser chamados a cumprir um papel diferente.

Embora a Tanlan esteja disponível para fazer shows inclusive em igrejas, situações distintas se configuram. A regra de que "não paramos nossos shows para fazer uma pregação" nem sempre é seguida à risca: "exceto quando tocamos em igrejas e os organizadores nos pedem isso".${ }^{16}$ Em agosto de 2017, durante a entrevista para um programa em que o objetivo geral era estabelecer as distinções entre palco e púlpito, os integrantes da banda observaram que eles podem participar do momento de louvor em um culto - até mesmo fazendo "solo de guitarra", se for adequado ao estilo da igreja em que estiverem - ou "dar uma palavra" no meio de um show. ${ }^{17}$ Na segunda entrevista, quando se fez menção a esse programa, Fábio relatou algumas situações. Às vezes são convidados para fazer "o culto todo com um show no final". Às vezes fazem o show no sábado à noite e participam do culto matinal do domingo, cantando um hino religioso ou apresentando alguma(s) das músicas da Tanlan com andamento mais lento. Na IBMS, em 2014, a banda fez um show, mas acoplou ao repertório próprio algumas músicas natalinas e foi acompanhada, em breves participações, pelo coral de alunos do Colégio Batista de Porto Alegre. Já na primeira entrevista para a pesquisa, Fábio notara que "quando pedem 'louvor', a gente faz - é como tocar um cover no bar". A analogia com o cover é interessante, pois tem como contrapartida algo que efetivamente ocorre em alguns shows da Tanlan, a performance ou menção a músicas de artistas seculares. Enquanto essa referência à música secular tem o efeito de apontar possíveis apropriações religiosas, a realização do "louvor" - ou de pregações - em igrejas pode cumprir o papel de reforçar que a Tanlan sabe ser uma "banda de crentes".

\footnotetext{
${ }^{15}$ O guitarrista da Tanlan havia se tornado, desde 2016, o responsável pela parte musical na igreja. ${ }^{16}$ Frase registrada em Muller (2014, p. 110).

${ }_{17} \mathrm{http}: / /$ bibotalk.com/podcast/btcast212/, acesso em 13/12/2017. No mesmo programa, a banda declarou saber de situações em suas canções şã̃o usadas em momentos de culto em igrejas ou outros locais.
} 
No Festival Promessas de 2017, a banda foi a primeira a se apresentar, no início da tarde, abrindo uma sequência de shows que se estenderia por horas até o anoitecer. Tal escalação pode confirmar a ideia de que a Tanlan produza um apelo menor em termos de público ou ter a ver com não integrar o cast da empresa que patrocinava a transmissão do evento. Como notou Fábio Sampaio: éramos "os patinhos feios" do festival. A Tanlan fez seu show, apresentando cinco músicas, a maioria de seu último álbum. Em uma delas, Fábio misturou-se ao público que cantava a canção. Depois, tiraram fotos e conversaram com as pessoas, recusando-se ao abrigo do backstage. Coisas que uma banda alternativa faz. Mas ainda no palco, no intervalo entre duas músicas, Fábio "deu uma palavra" - não mencionou Jesus, e sim a importância de se usar o tempo para se dedicar aos outros. Isso já era parte da performance de "A Maior Aventura”, cuja letra mencionei acima para ilustrar a teologia da Tanlan. Ou seja, na perspectiva dessa teologia, o comentário não deixava de ser uma pregação. Outra música propiciou o momento para estabelecer uma conexão com o público predominante do festival - que certamente não era de fãs da Tanlan. A banda entoou um conhecido hino evangélico, no que foi acompanhada pela multidão. Fábio explicou, na entrevista, que o hino tinha a ver com a música. A música era "Epifania", como já sabemos, a mais "confessional" do último álbum e, como disse o vocalista, que "pode ser cantada em um momento litúrgico".

\section{Conclusões: até onde o gospel vai e até onde ele deixa ir}

No livro que dedica ao estudo de uma organização de propagação do cristianismo na Inglaterra, Engelke (2013) afirma: “Para a antropologia, o oposto de cultura é natureza. Para evangélicos, o oposto de cultura é a Igreja" (p. 70). Se a observação soa simplificadora quando se trata da antropologia, ela certamente capta algo relevante acerca dos religiosos. No caso dos evangélicos acompanhados por Engelke, o desafio seria entrar em sintonia com essa "cultura" que define o mundo que está fora da "Igreja" e que esta pretende transformar. 
Mais especificamente, o trabalho consistia em elaborar uma campanha para aproximar a Bíblia das pessoas comuns, capaz de mostrar ao mesmo tempo sua contemporaneidade e sua excepcionalidade. A solução encontrada, com a ajuda de uma agência de publicidade, foi produzir uma espécie de charada. A charada envolvia conhecimento bíblico, mas sua divulgação recorreu a linguagens e suportes que pretendiam revelar familiaridade com a "cultura secular". A análise de Engelke passa por aspectos que articulam conteúdo e forma, mensagem e suporte. Ela oferece, em minha opinião, pistas valiosas para apreendermos alguns dos sentidos e propósitos dos evangélicos que aparecem como protagonistas nas narrativas expostas neste texto.

Podemos começar com algo que Fábio Sampaio nos conta que fala nos shows da Tanlan: “'Pegue o nosso CD e dê para aquele seu amigo universitário que jamais ouviu uma banda gospel'. Por quê? Porque ele pode gostar do som. E a letra não vai criar um bloqueio. Ele não vai ouvir e dizer: 'cara, essa música é música de crente'. Ele vai ouvir. Pode ser que ele goste, ou não. Mas se ele gostar é por causa da música. 'Se ele gostar, converse sobre as letras com ele'. É assim que a gente acha que as coisas podem acontecer". Esse é um enunciado muito revelador do que a Tanlan pretende ser: "uma banda formada por cristãos acessível a todos ou uma banda que alcançasse dois mercados [gospel e secular] sem criar barreiras entre eles" ${ }^{18} \mathrm{O}$ paradoxo das situações sugeridas por Fábio é que elas se resolvem ou encontram equação apenas quando se considera a identidade cristã da banda. A contrapartida dessas situações poderia ser o texto, grafado em tipografia contemporânea, que esteve em algum momento na fachada do templo da IBMS: "Proibida a entrada de pessoas perfeitas". A estética com que se mostra a IBMS revela seu desejo de sintonia com a modernidade, entendida como o caminho para se produzir transformações. É isso que parece sugerir o material disponível no site da IBMS relacionado com a frase acima: “Venha como está, mas não permaneça do mesmo jeito". ${ }^{19}$

\footnotetext{
${ }^{18}$ A frase está registrada em Muller (2014, p. 112).

${ }^{19}$ https://www.igrejabatista.org.br/memorial, acesso em 13/12/2017.
} 
As situações evocadas acima podem ser discutidas e desdobradas com a referência à ideia de cultura. Um primeiro ponto tem a ver com o tema do preconceito. Ele surge no efeito pretendido no lema da IBMS: contrapor-se à noção comum de que a igreja seja um lugar de pessoas perfeitas. $\mathrm{O}$ tema surge algumas vezes nas entrevistas com Fábio, que gosta de mencionar situações capazes de "quebrar o preconceito" que existe - segundo ele, às vezes por razões compreensíveis - contra os evangélicos. Essa preocupação expressa-se em uma atitude que se pretende, como aponta Jungblut (2007: 155), contracultural. Ou seja, a ideia de que algo como o rock feito por uma banda como a Tanlan é que realmente se contrapõe a valores dominantes, exemplificados com menções a consumismo, hedonismo, materialismo, etc. Isso aparece nas letras de músicas, como a já citada "Bem Vindo" ("Será mais um na multidão / ou será a voz que vai na contra-mão?") e na faixa que abre o terceiro CD - "Eles Dizem": “Todos eles dizem, você precisa se encaixar / Ser igual aos outros e não tentar mudar". Mas há ainda outra dimensão em que desponta o sentimento de preconceito, quando Fábio observa: “a MPB é recheada de música afro, de religião afro. E ninguém chama isso de 'umbanda music'. É 'MPB'”. Por que então, pergunta o vocalista da Tanlan, uma banda cuja música "vai estar repleta e recheada de cristianismo" precisa ser rotulada como "gospel"?

Esse ponto leva a um segundo, no qual o que está em jogo é exatamente a ação pela e sobre "a cultura". Para a Tanlan, a proposta de "usar a música para evangelizar" é inócua se essa música não é capaz de extrapolar o circuito das igrejas e dos eventos por elas promovidos. Optando por fazer uma música que pudesse ser apreciada por suas qualidades intrínsecas - como "arte" - a banda aposta que pode atingir públicos mais amplos. Nas suas próprias palavras, engaja-se na missão de "influenciar a cultura". Segundo Fábio, quando se trata disso, não há que se ter "uma cultura paralela" e sim "estar onde a cultura acontece". ${ }^{20}$ Daí a ideia de fazer shows em bares: "os caras vão ter a oportunidade

\footnotetext{
${ }_{20}$ Para o mesmo ponto, ver http://bibotalk.com/podcast/btcast212/, acesso em 13/12/2017.
} 
de ver um jeito diferente de vida". Esse jeito diferente é evidenciado seja pela postura como artista, seja em uma vida que "condiz com aquilo que canto". A expectativa é que tal atitude tenha um poder transformador. Em resposta ao diagnóstico de que há "várias matrizes ideológicas, filosóficas e religiosas inseridas na cultura" (o vocalista exemplifica com referências afrorreligiosas, LGBT e visões materialistas), o desafio seria conquistar espaço para o cristianismo, às vezes expresso como "matriz cristã". Não se pode deixar de notar a ambiguidade entre ter e ampliar esse espaço, que se traduz na expectativa de transformação. Assim termina a letra de "Eles Dizem": "Sinta o que é real / Vida que vai, vida que vem / Não há nada que se mude o que se tem / Sem primeiro mudar você".

Para arrematar a visão aqui elaborada sobre a Tanlan, é interessante nos reportarmos ao texto de Howard e Streck (1996). Dedicados a traçar uma tipologia que contemple as tensões que percorrem o universo da "música cristã contemporânea" nos Estados Unidos, os autores recorrem exatamente ao par "Cristo" e "Cultura". A ênfase na contraposição entre Cristo e Cultura produziu o gênero separacionista, com suas letras explícitas sobre a mensagem de salvação trazida pelo cristianismo. A possibilidade de imaginar a adaptação dessa mensagem à cultura engendrou, por sua vez, o gênero integrativo, que pretende conviver com seus correspondentes seculares, com letras que falam do valor do esforço individual e do amor. Enfim, há um terceiro gênero, rotulado de transformacional pelos autores, que surge do reconhecimento de que a vida religiosa apresenta desafios similares aos encontrados na vida secular, o que produz críticas tanto às igrejas quanto às estruturas da sociedade. Como Howard e Streck admitem, um mesmo artista pode, na sua trajetória, oscilar entre esses três gêneros. No caso da Tanlan, depois do que vimos, eu afirmaria que sua proposta como banda busca cobrir, ao mesmo tempo, as três vertentes.

Voltemos agora à IBMS para registrar o comentário de um membro acerca da Tanlan. Lembrando da apresentação descrita acima, esse fiel ponderou que a banda não era "muito chamada" porque se tratava de uma "banda para show" e 
a Festa de Levi "seria mais para ministração". O comentário é relevante em vários sentidos. Em relação à Tanlan, expressa os desafios que ela enfrenta para concretizar sua proposta. Notamos que há dificuldades para transitar no circuito não religioso. E agora vemos que a banda se depara com ressalvas para sua apresentação em uma igreja. Mas é importante lembrar que, na prática, os músicos da Tanlan podem aquiescer em incorporar a ministração a suas apresentações - o que, vale repetir, sinaliza para a pressão que sofrem para se aproximarem do gospel enquanto rótulo. Quanto à IBMS, o comentário do fiel aponta para a operação dos critérios que marcam o espaço eclesial como espaço propriamente religioso. Um religioso, contudo, aberto a estilos e estéticas que dialoguem com o não religioso. Mais do que isso, um religioso que investe na capacitação dos músicos, como declara o pastor que lidera o ministério de louvor da IBMS: "trazendo a consciência de que não é apenas um hobby, mas uma responsabilidade que eles têm, no sentido de construir a visão da música brasileira, música cristã, a partir da nossa igreja". Ou seja, a evidenciar as potencialidades desse investimento, talvez estejam em gestação novas "tanlans"...

Gormly (2003) argumenta que a "música cristã contemporânea" tem como efeito o aumento da presença cultural da mensagem cristã nos Estados Unidos. Já Garma (2000), tratando do México, parece apostar, quando se trata da "música cristã", no fortalecimento das estruturas internas ao universo religioso. É difícil dizer quem tem mais razão, até porque os dois resultados não são inconciliáveis. De toda maneira, não foi essa a questão central deste texto. Preocupei-me mais em problematizar, tendo como foco o Brasil, os processos de definição da música gospel. Dialogando com outros trabalhos, busquei mostrar que esses processos envolvem o estabelecimento de limites. No caso da IBMS, tais limites incidem sobre os modos de presença da música em atividades de culto. No caso da Tanlan, nos deparamos com uma banda que pretende questionar os limites entre o religioso e o não religioso. Nos dois casos, vimos como ocorrem dinâmicas que operam para atenuar e repor limites. Minha abordagem procurou mostrar a 
mobilidade das fronteiras em torno das quais se constitui a música gospel e os desafios que isso coloca do ponto de vista seja de uma igreja evangélica, seja de um conjunto de artistas. O que confere realidade aos limites é exatamente sua relatividade, transformando sua natureza de acordo com as posições (igrejas, artistas) que os encontram e definem.

\section{Referências}

BANDEIRA, Olívia. O mundo da música gospel entre o sagrado e o secular: disputas e negociações em torno da identidade evangélica. Rio de Janeiro: Tese de Doutorado, Programa de Pós-Graduação em Sociologia e Antropologia, 2017. CHANG, Paul Y.; Dale J. Lim. Renegotiating the Sacred-Secular Binary: IX Saves and Contemporary Christian Music. Review of Religious Research, Vol. 50, No. 4 (Jun., 2009), pp. 392-412.

ENGELKE, Matthew. God's Agents: Biblical Publicity in Contemporary England. Berkeley: University of California Press, 2013.

FORNACIARI, Christina. "Funk e religião". In: Funk da gema: de apropriação a invenção, por uma estética popular brasileira. 2011, pp. 47-56.

GARMA, C. (2000). Del himnario a la industria de la alabanza: un estudio sobre la transformación de la música religiosa. Ciencias Sociales y Religión, 2 (2), 63-85. GORMLY, Eric (2003) Evangelizing Through Appropriation: Toward a Cultural Theory on the Growth of Contemporary Christian Music, Journal of Media and Religion, 2:4, 251-265.

GUERREIRO, Clayton. “Do 'circo' à 'macumba' pentecostal: sobre categorias acusatórias e justificações". In: Melvina Araújo e Christina Vital da Cunha (orgs.). Religião e Conflito. Curitiba: Prismas, 2016, p. 195-216.

HOWARD, Jay R.; John M. Streck (1996). The splintered art world of Contemporary Christian Music. Popular Music, 15, pp 37-53.

JUNGBLUT, A. (2007). A salvação pelo rock: sobre a cena underground dos jovens evangélicos no Brasil. Religião e Sociedade, 27 (2), 144-162.

MOSQUEIRA, Mariela Analía; "Hasta lo último de la tierra" : Consolidación y transnacionalización del rock cristiano argentino. Journal of the Sociology and Theory of Religion; 5; 2016; 77-101.

MULLER, Ursula Gabriela Brehm. Contracultura Gospel - Um Estudo de Caso da Banda Tanlan. Trabalho de Conclusão de Curso. Graduação em Comunicação Social (Publicidade e Propaganda). São Leopoldo, UNISINOS, 2014.

NOVAES, Regina. Ouvir para crer: os racionais e a fé na palavra. Religião e Sociedade, Rio de Janeiro, v. 20 (1), 1999, p. 65-92.

OLIVEIRA, Marina de. Rock, identidade e juventude no underground evangélico brasileiro. Monografia (Bacharelado e Licenciatura em História)-Universidade de Brasília, Brasília, 2013. 
OOSTERBAAN, M. (2015). Gospel Funk - Pentecostalism, Music and Popular Culture in Rio de Janeiro. In Monique M. Ingalls \& Amos Yong (Eds.), The Spirit of Praise - Music and Worship in Global Pentecostal-Charismatic Christianity (pp. 262-278). University Park: Penn State University Press.

PAULA, Robson R. . O mercado da música gospel no Brasil: aspectos organizacionais e estruturais. Revista UNIABEU , v. 5, p. 141-157, 2012.

SANT'ANA, Raquel. A nação cujo Deus é o Senhor: a imaginação de uma coletividade evangélica a partir da Marcha para Jesus. Rio de Janeiro: Tese de Doutorado, Programa de Pós-Graduação em Antropologia Social, 2017.

TANLAN. Tudo o que Eu Queria. CD, independente, 2008.

TANLAN. Um Dia a Mais. CD, Sony Musica, 2012.

TANLAN. Acalmanocaos. CD, Sony Musica, 2016. 